\title{
Diacronie
}

Studi di Storia Contemporanea

$\mathbf{N}^{\circ} 21,1 \mid 2015$

Le città di Babele

\section{The Eighth Vibration. Asmara and Dek'emhare, Cities of Work, Cities of Leisure}

\section{Gian Luca Podestà}

\section{(2) OpenEdition}

Journals

\section{Electronic version}

URL: http://journals.openedition.org/diacronie/1919

DOI: 10.4000/diacronie. 1919

ISSN: 2038-0925

\section{Publisher}

Association culturelle Diacronie

\section{Electronic reference}

Gian Luca Podestà, «The Eighth Vibration. Asmara and Dek'emhare, Cities of Work, Cities of Leisure », Diacronie [Online], № 21, 1 | 2015, document 8, Online since 01 March 2015, connection on 30 April 2019. URL : http://journals.openedition.org/diacronie/1919 ; DOI : 10.4000/diacronie.1919 


\title{
Diacronie
}

\section{8/}

\section{The Eighth Vibration. Asmara and Dek'emhare, Cities of Work, Cities of Leisure}

\author{
Gian Luca PODESTÀ *
}

The case of Asmara was emblematic. In 1934 Asmara had a population of about 3,500 Italians and 12,000 Africans. In 1939 Italians had risen to 48,000 whilst Africans were 36,000. In just five years the total population had increased fivefold, whilst the proportion between Italians and indigenous people had been reversed. This was an unprecedented phenomenon, determined by the economic importance of the city as a logistic base for the war. Asmara became the financial hub of the new Italian empire, where all major Italian companies had opened branches, as well as the seat of hundreds of new business enterprises born after the conquest of Ethiopia. Social life in Asmara was pulsating just like that of any other European town. During the day the heart of the city throbbed with business, both in the street markets and in the new Italian districts, where the offices of trading and industrial companies could be found. At night, social life moved to the ever expanding number of entertainment and leisure facilities. New dancehalls, restaurants and bars were being opened everywhere. The working men's clubs and numerous sports and recreational societies, supported by local government and by the PNF, organised the colonists' free time. In Eritrea, near the strategic hubs where companies and the army had located their logistic bases, new urban agglomerates rose from scratch, such as Dek'emhare and Nefasit, with plenty of restaurants and clubs, patronised by military personnel, workers and by the Italian nouveaux riches who, as Indro Montanelli denounced in his book "XX Battaglione Eritrea" (20th Eritrean Battalion) lived a upper-class lifestyle, which went against the Fascist imperial ethos, thus betraying the ideal purpose of the African wars. 


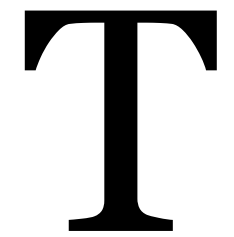

he conquest of Ethiopia radically modified Italian colonial policy, shifting it onto another level, that of the empire. The empire, in Mussolini's opinion, was above all a spiritual goal towards which Italians should strive in order to avoid the fate of decadent Western people. The meaning attributed to the term transcended the mere material increase in the size of conquered territories, assuming an almost metaphysical character. Fascism's idea of empire conceived a new totalitarian colonial policy, which included some common guidelines for the colonies (such as the racial hierarchy and the school programmes), thus overcoming the historical, political and cultural heterogeneity of the various dominions, and also taking into account that one of the principal objectives was to create large Italian communities overseas. To highlight the differences between the fascist model and the classic colonialism of the other European powers, and underline its communitarian outlook, jurists defined the fascist empire as a corpus mysticum made up of several parts which, however, «although they all concurred to reach the same common goals and though each obtained its own advantage» ${ }^{1}$, were not on the same level: first came Italy and Albania, followed by Libya and the Italian islands in the Aegean sea; AOI came last.

Of course the elements concurring to make up the hierarchy of dominions were mainly racial and cultural. The administration of the territories was also differentiated: the Aegean Sea and Albania, which was part of the imperial community as an autonomous and independent entity associated to Italy, depended on the Foreign Ministry, whilst Libya and AOI depended on the Ministry for Italian Africa (Ministry of Colonies until 1937), which had purposely changed its name to underline the new way to conceive the relationship between the colonies and the motherland. Between 1936 and 1940, in all its overseas possessions, including Albania and Rhodes, the fascist regime elaborated demographic colonization plans for the transfer of Italian colonists. The emigration of select Italian families represented one of the cornerstones of fascist policy. The common traits, which bore witness to the universal vocation of imperial policy (whose objectives were chiefly the shaping of the new Italian colonists as well as raising the degree of "Italianness" of indigenous populations), concerned the creation of schools both for Italian and autochthonous students; archaeological research; the diffusion of newspapers and magazines (including some in the local languages), the cinema, theatres and the radio; the spreading of Western and/or typically Italian

\footnotetext{
${ }^{1}$ AMBROSINI, Gaspare, L'Albania nella comunità imperiale di Roma, Roma, Quaderni dell'Istituto Nazionale di Cultura Fascista, 1940, p. 63.
} 
lifestyles and leisure pastimes; the planning of an overseas Italian architecture; the founding of cultural and sports institutions.

The new Italian settlers enjoyed notably larger incomes compared to Italians back home. This modified their lifestyle, increasing the popularity of cultural and sports activities some of which, such as tennis and horse-riding, represented a rise in social status. This phenomenon also touched that part of the African population in direct contact with Italians. Schools and the Fascist Party (PNF) were the institutions in charge with the spreading of culture and sports. All tourist and sports facilities were either built by the government of by the PNF.

The Party looked after Italians' leisure time through some collateral bodies: if the Institute of Fascist Culture, the Fascist University Groups (GUF) and the Italian Lictorian Youth (GIL) prevalently dealt with political and cultural indoctrination as well as physical education, the Working Men's National Association (OND, Opera Nazionale Dopolavoro) played an important role in the involvement of its members in cultural, leisure and sports activities, which favored the aggregation of large numbers of people and the strengthening of the feelings of "Italianness". The creation of the Arab Lictorian Youth (GAL) in Libya and the Indigenous Lictorian Youth (GIL) in East Africa also allowed the PNF to organize and form the younger natives. The diffusion of Western sports, such as football, in African schools or among the young members of GAL and GIL integrated the young subjects' education.

The Italian Touring Club also played a crucial role in the empire's cultural and tourist promotion, both by organizing trips and events, and above all through its own publications. Besides fascist institutions a remarkable number of sports, cultural and military associations helped to manage the colonists' leisure time.

Imperial publications were generally published by the government or by the Fascist Party and therefore had an official character, but there were also some catholic magazines, whilst cinemas and theatres were growing in numbers. The cinema was also a formidable political and cultural tool in the process of assimilation of subject people, as the Under-secretary to the Italian Foreign Office, Zenone Benini, highlighted in one of his reports to Mussolini on Italian cultural penetration in Albania, though his remarks can be extended to all other dominions:

For the purpose of spiritual elevation, educational activities are and will be more and more supported [...] by the action of those technical means, such as cinema and the radio, which are especially apt to take the educating voice of Italian civilization to the most isolated outposts [...] To this aim [...] several itinerant 
cinemas have been sent which, as well as broadcasting everywhere the beauty of Italian sights, provide the first recreational occasions for the masses ${ }^{2}$.

Table 1. The population of Italian empire in 1939 (estimate)3

\begin{tabular}{|l|l|l|}
\hline & Population & Italians \\
\hline Libya & 893.774 & 119.139 \\
\hline Italian East Africa (AOI) & 12.100 .000 & 165.267 \\
\hline Aegean Islands & 140.848 & $16.711^{*}$ \\
\hline Albania & $1.037 .856^{* *}$ & $?$ \\
\hline Tien-Tsin (China) & 9.017 & $?$ \\
\hline Total & 14.181 .495 & 301.117 \\
\hline
\end{tabular}

* Soldiers included.

** The 31 december 1937 .

\section{Asmara and Eritrea 1936-1941}

In AOI the Duce intended to create a new organic social system conjugating demographic colonization with other forms of valorization, transferring from Italy «the whole machinery of its own civilization ${ }^{4}$. Fascist colonization should be understood, in space and time, as «the settlement and empowerment of a people»5, that is the transposition to the colonies of all the productive elements of the mother country, such as farmers, workers, artisans, clerks, traders, small entrepreneurs and intellectuals, thus shunning the loathsome model of capitalistic colonization exclusively aimed at benefiting a restricted class of privileged individuals. This conception met with three crucial objectives: preserving and increasing the country's numerical power, cementing Italians' racial cohesion in the empire and in Italy itself and, finally, promoting the social elevation of large popular masses.

There are no precise data on the European and African population in AOI. An estimate carried out in the spring of 1939 indicated 165,267 Italian civilians, against

2 Ibidem, p. 66.

3 Istituto Fascista dell'Africa Italiana, Annuario dell'Africa Italiana e delle Isole Italiane dell'Egeo 1940-A. XVIII, Roma, Società Tipografica Pio X, 1940.

4 MEREGAZZI, Renzo, «Lineamenti della legislazione per l'Impero», in Gli Annali dell'Africa Italiana, 3/1940, p. 12.

5Ibidem. 
about 12 million Africans. The greatest number of settlers, amounting to 72.408 lived in Eritrea (43.8\%). The percentage of women was very small and only in Eritrea did it exceed 20\%: in 1939 there allegedly were 26.628 women, of whom 14.827 in Eritrea $(55 \cdot 7 \%)$.

Table 2. Italian civilians in AOI (1939)6

\begin{tabular}{|l|l|l|}
\hline District & Italian civilians & $\%$ \\
\hline Eritrea & 72.408 & 44,0 \\
\hline Scioa & 40.698 & 25,0 \\
\hline Somalia & 19.200 & 11,0 \\
\hline Galla e Sidama & 11.823 & 7,0 \\
\hline Amara & 11.103 & 7,0 \\
\hline Harar & 10.035 & 6,0 \\
\hline Total & 165.267 & 100,0 \\
\hline
\end{tabular}

Table 3. Italian women in AOI (1939) 7

\begin{tabular}{|l|l|l|}
\hline District & Italian women & $\%$ \\
\hline Eritrea & 14.827 & 20,4 \\
\hline Scioa & 6.564 & 16,3 \\
\hline Somalia & 2.287 & 11,9 \\
\hline Harar & 1.350 & 13,4 \\
\hline Amara & 946 & 8,5 \\
\hline Galla e Sidama & 654 & 5,7 \\
\hline Total & 26.628 & 100 \\
\hline
\end{tabular}

Mussolini constantly urged the need to increment the number of families, in order to balance the ratio between the two sexes. Il Duce was obsessed with racism. He was above all horrified by the sexual promiscuity of Italian workers and soldiers with African women, about which since 1935 he had been receiving hundreds of alarming reports that deplored the increase in the birth of mixed-blood children ${ }^{8}$; he had even discussed this subject with the foreign press. The issuing of racial legislation, from spring 1937 onwards, was a consequence of the decision to force settlers to take their families with them to the colonies. Unfortunately the problem was not so easy to solve, because African towns did not yet possess a sufficient number of homes or the necessary services. The management of the demographic colonization program was delegated to the Opera Nazionale Combattenti (ONC, the War Veterans' National Organization) and to some regional bodies depending on the PNF. Until 1940,

\footnotetext{
${ }^{6}$ CIFERRI, Raffaele, «I cereali dell'Africa Italiana», in Rassegna economica dell'Africa Italiana, 1/1942, p. 12; Istituto Fascista dell'Africa Italiana, Annuario dell'Africa Italiana e delle Isole Italiane dell'Egeo 1940-A. XVIII, Roma, Società Tipografica Pio X, 1940.

${ }^{7}$ Popolazione nazionale femminile residente in AOI e iscritte ai fasci femminili al 31 dicembre 1939, ACS, MAI, b. 2123.

${ }^{8}$ The Ministry for Italian Africa to the AOI General Government, 24 September 1938, ASDMAE, ASMAI, ASG, b. 70.
} 
according to data published by the Italian press, the farmer families already settled in their plot were 854, whilst more reliable sources reduce their number to $377^{9}$.

Most Italians of course lived in the towns. But the increasing number of new arrivals between 1936 and 1938 caused great difficulties to colonial governments, who were totally unprepared as regards housing and other urban services (water, electricity, gas, transport, etc.).

The situation in Asmara was quite exceptional. The population, which in 1935 amounted to 4.000 Italians and 12.000 Africans, had grown in 1939 respectively to 48.00o and 36.000. It was a phenomenon without precedents in history, determined by the town's economic importance as a logistic base for the war. Its housing problem was also dramatic: families coped as best as they could, whilst many single men were even forced to sleep in their vans. The wave of new immigrants had generated cohabitation problems with the older generation of colonists, who looked contemptuously on the new arrivals. In practice Asmara had become an Italian city. The presence of a white community of such proportions (there were in total over 72.00o Italians living in Eritrea), had produced an exceptional growth in economic activities. There were thousands of industrial, commercial and artisan enterprises registered in the region. By 1938, over 12.000 civilian vehicles were already circulating in Eritrea (one every six inhabitants), of which 4.000 cars and 8.00o vans.

Private housing therefore played a more relevant role in Asmara. On the outskirts of the city there were vast areas suitable for building. The new residential quarters, built in typical Italian style in the suburbs of the town and characterised by two or threestorey buildings, were symbolically facing the old town centre made up of one-storey houses, occupied by the indigenous population, attracted there by the growing demand for labour. To plan the new city, the Ministry sent the architect Vittorio Cafiero to Asmara $^{10}$. The planning scheme elaborated in 1939 recalled the general outlines set out for the plan of Addis Ababa, although in this case the situation was different. The new project in fact contradicted the arrangement of the indigenous area carried out in the previous years by the chief of the Technical Office, another architect called Guido Ferrazza, providing for the forced removal of the African quarter, the caravanserai and the mosque. The Governor of Eritrea, Giuseppe Daodiace, a colonial civil servant of great experience, though accepting the general features of the project, refused to evict

\footnotetext{
9 SBACCHI, Alberto, Il Colonialismo italiano in Etiopia 1936-1940, Milano, Mursia, 1980, p. 324 .

10 «I piani regolatori», in Gli Annali dell'Africa Italiana, 4/1939, p. 383; «Le opere edilizie», in Gli Annali dell'Africa Italiana, 4/1939, p. 442.
} 
the natives from their quarters, underlining the loyalty Eritreans had always shown toward Italy. Thus Asmara maintained at its core an indigenous zone that contradicted the regime's racial policy and that, as has been highlighted, determined the "peculiar social structure that the town maintained for a long time after the war» ${ }^{11}$.

Besides workers, the military and all those who depended on the public administration (including those with a temporary contract), and private companies' employees (including banks and insurance companies), a large number of Italians, not quantifiable but certainly amounting to some tens of thousands, had set up their own business. These were hard-working people who had shown great adaptability, initiative and inventiveness. A multitude of small entrepreneurs, traders, managers of small, often itinerant, catering businesses, drivers and owners of means of transport, skilled workers who doubled as artisans, owners of small building firms, trade representatives and intermediaries.

In April 1939 the MAI carried out a survey of Italian industrial and commercial enterprises registered in AOI and their invested capitals. There were 4,007 industries with a total capital of over 2.7 billion of current lire. The highest concentration of businesses and capitals was in Eritrea with 2,198 companies (54.8\%) worth about 2.2 billion current lire (80.4\%), followed by Shewa with 561 (14\%) with 305 million (11.1\%); Somalia had 584 private businesses (14.5\%) with a capital of about 75 million (2.7\%). The most relevant sector was road transport with 1,262 private businesses (31.5\%) worth about 1.7 billion lire (62.2\%) followed by building with 823 companies (20.5\%) with invested capitals amounting to about 745 million lire (27\%). Commercial enterprises were 4,785 with invested capitals of over $£ 1.1$ billion. Economically, the most important regions were Eritrea with 2,690 businesses (56.2\%) worth about 486 million lire (43.7\%) and Shewa with 634 businesses (13.2\%) valued at about £500 million (45\%).

As regards authorization for the most relevant economic activities (those with company capital over 500,000 lire), the entertainment and oil businesses with any capital investment as well as transport enterprises (with at least ten vehicles), the Ministry for Italian Africa (MAI) had sole charge, though it reached its decisions after asking for the opinion of the various Councils. According to statistics, in May 1939,

\footnotetext{
${ }^{11}$ GRESLERI, Giuliano, 1936-4O: programma e strategia delle "città imperiali», in GRESLERI, Giuliano, MASSARETTI, Pier Giorgio, ZAGNONI, Stefano (eds.), Architettura italiana d'oltremare 1870-1940, Venezia, Marsilio, 1993, p. 198. The governor of Somalia, Francesco Saverio Caroselli, was also against moving the old mosques from the centre of Mogadishu. Governo Generale AOI. Direzione Superiore Affari Civili a Ministero dell'Africa Italiana, 10 March 1940, ACS, MAI, b. 104.
} 
1,140 companies with a registered capital over 500,000 lire had obtained a license; 499 of these were already active in the empire ${ }^{12}$. Out of them, 407 had already set up industrial facilities, whilst the remainder had only created a commercial network. Most companies worked in the building sector (193), mechanics and metallurgy (59), foodstuffs and drinks (48), transports (38), chemicals (34), construction materials (29) and timber (25). As many as 28 licenses had been granted to the entertainment industry (cinemas and theatres). To alleviate at least partially the housing problem and create the premises for future tourist development, the State created the Campania Immobiliare alberghi Africa Orientale (CIAAO - East African Hotel Construction Company, established to build hotels in the largest cities ${ }^{13}$. In AOI the relationship between the number of businesses and the resident population was therefore rather high. This phenomenon was more evident in Eritrea, the most important region in terms of Italian settlers, number of companies, amount of capitals invested and weight of the private sector compared to the public sector. In summer 1939 the MAI published new data concerning Eritrea that also included smaller enterprises and retail dealers ${ }^{14}$. Commercial enterprises were 5.174, whilst 653 were registered as activities auxiliary to trade (banks, insurance companies, brokers and shipping companies). Industries had risen to 2.769 , while there were 1.737 registered artisans. In total 10.333 Italian business enterprises had been recorded (1.209 restaurants and public bars).

Paradoxically, although Mussolini had declared that the empire's true wealth consisted of Italian people's work, the new economic situation managed to involve a consistent part of the African population too. Both the State and private businesses needed labour. In 1940 estimates recorded 750.000 African workers employed in constructions, road-building and agriculture. If we add those recruited by the armed forces and those working for private businesses, their number surpasses one million, about $10 \%$ of the estimated African population. In the agricultural sector too, the planned emigration of Italian farmers had been suspended for financial reasons, deeming more opportune to involve African farmers and their families in copartnership agreements. In the road-building sector, despite Mussolini's orders to avoid intermingling between the races, at the end of 1938 thousands of Africans were still working side by side with Italian workers 15.

${ }_{12}$ Confederazione Fascista degli Industriali, Lindustria in Africa Orientale Italiana, Roma, U.S.I.L.A.,1939, p. 361.

13 PODESTÂ, Gian Luca, Il mito dell'impero. Economia, politica e lavoro nelle colonie italiane dell'Africa orientale 1898-1941, Torino, G. Giappichelli, 2004, p. 308.

14 "Attività economiche esercitate nell'Eritrea al 30 aprile 1939", in Rassegna economica dell'Africa Italiana, 8/1939, pp. 765-766.

15 «Le opere stradali», in Gli Annali dell'Africa Italiana, 4/1939, p. 325. 
In Addis Ababa the situation was different. The capital of the empire was due to become, in Mussolini's opinion, the most beautiful and futuristic city in Africa, the beacon of the new fascist civilization ${ }^{16}$. The preparation of the new town planning scheme was very long and problematic ${ }^{17}$, involving top professional people like Giò Ponti, Enrico Del Debbio, Giuseppe Vaccaro $^{18}$ and even Le Corbusier, who asked il Duce to be allowed to design the plan for the new city ${ }^{19}$. Work only started in 1939 . The plan provided for a clear separation between the European and indigenous areas. However, this would have meant transferring the African population and building tens of thousands of new homes. Italian settlers had increased from a few thousands in early 1937 (with 150 families) to over 40,000 in March 1940 (33.059 men, 6.998 women and about 4,00o families) whilst the African population had practically doubled and was estimated at about 120,000 people- In Addis Ababa the number of new-born babies was continually growing, rising from 50 in 1937 to 570 in 1939 and the number of weddings being celebrated shot up too, despite the dramatic housing shortage. Italians coped in all possible ways: many continued to live in temporary shelters (tents, huts and prefabricated houses), whilst a lot of families used indigenous homes that had been expropriated or rented. Mussolini found this situation intolerable, and he constantly urged the Italian East Africa's government to ensure a more vigorous policy of racial separation (on his orders the African market had been forbidden to Europeans, but the measure was later withdrawn, because indigenous trade was indispensable for the provision of food by whites) ${ }^{20}$. As Amedeo d'Aosta once remarked, the solution of the problem of racial prestige was incompatible with the housing situation: firstly, there was not enough money to build houses for Italians or tukuls in the new indigenous town, then there were huge difficulties in sourcing water and building materials; that is why most Ethiopians, after cashing in their expropriation indemnity, went back to the

16 PODESTÀ, Gian Luca, «L'émigration italienne en Afrique orientale», in Annales de démographie Historique, 1/2007, pp. 59-84.

${ }_{17}$ Governatorato di Roma. Progetto per il piano regolatore di massima della città di Addis Abeba. Relazioni, ACS, MAI, b. 104.

18 Rapporto degli architetti Del Debbio-Ponti-Vaccaro sulla costruzione di Addis Abeba, 7 dicembre XV (1936), ACS, MAI, b. 104. Del Debbio stayed longer in the colony than his companions.

19 TALAMONA, Marida, «Addis Abeba capitale dell'impero», in Storia contemporanea, 56/1985, p. 1093; GRESLERI, Giuliano, La "nuova Roma dello Scioa", in GRESLERI, Giuliano, MASSARETTI, Pier Giorgio, ZAGNONI, Stefano (a cura di), Architettura italiana d'oltremare 1870-1940, Venezia, Marsilio, 1993, pp.165-177.

${ }_{20}$ «To prevent from the start the terrible and not so distant effects of race mixing, it is prohibited to all Italians, military or civilians, to remain for more than six months in the colonies without a wife [...] information also coming from foreign sources render these measures very urgent». Written by Mussolini to Badoglio, 11 May 1936, SUSMEL, Edoardo, SUSMEL, Duilio (a cura di), Opera Omnia di Benito Mussolini, vol. XXVIII, Firenze, La Fenice, 1959, p. 263 . 
old quarters. To confront the situation, given that, as the Viceroy repeated, it was impossible to separate the two races «by evicting one hundred thousand natives» ${ }^{21}$, and whilst waiting for the implementation of a low-cost building program for the colonists, it was necessary to stop new family units emigrating to Italian East Africa-To house the families of AOI government employees, who had been forced by Mussolini to take their wives and children to Africa, the national housing body for civil servants (INCIS, Istituto Nazionale Case degli Impiegati dello Stato) financed the construction of 42 buildings with 119 flats, largely insufficient to satisfy all requests ${ }^{22}$. Private individuals did not have any incentives to invest in residential building save for exceptional cases. Notwithstanding the "winds of war", only in July 1939 a law was emanated which authorized banks operating in AOI to grant loans and mortgages to institutions, societies or private citizens who wished to build civilian houses (including cheap homes), and the planning schemes of the most important towns were completed only on the eve of $\mathrm{WW}^{23}$. The war definitely put an end to all works in progress, and today the traces of Italian occupation are absolutely insignificant.

But if the new imperial cities had trouble in taking shape, social life in Addis Ababa and Asmara was pulsating just like that of any other European town. At the heart of the city were the markets: in the capital in 1939 over 75.000 heads of cattle had been slaughtered and thousands of tons of foodstuffs had been sold. Dozens of shops and even department stores were opened in both cities. Leisure activities also boomed: in Addis Ababa four cinemas had been built for Europeans and one for Africans; eight were functioning in Asmara ${ }^{24}$.

New dance-halls, restaurants and bars were being opened everywhere. The working men's clubs and numerous sports and recreational societies, supported by local government and by the PNF, organized the colonists' free time. In Eritrea, near the strategic hubs where companies and the army had located their logistic bases, new urban agglomerates rose from scratch, such as Dek'emhare and Nefasit, with plenty of

${ }^{21}$ Amedeo d'Aosta writing to Ministero dell'Africa Italiana, 29 March 1940, ASDMAE, ASMAI, $A S G$, b. 70.

${ }_{22}$ Città di Addis Abeba. Relazione dell'attività svolta dagli uffici dell'amministrazione municipale dal gennaio 1939 all'aprile 1940, ACS, Fondo Graziani, b. 46.

23 From Carlo Boidi (Mayor of Addis Ababa) to Governo Generale AOI, 25 May 1939, ASDMAE, ASMAI, ASG, b. 22.

Promemoria per S.A.R. il Duca d'Aosta viceré d'Etiopia inerente i problemi più urgenti della città di Addis Abeba, 21 June 1939, ASDMAE, ASMAI, ASG, b. 22. Italy's participation in the war put an end to public and private building works. The whole building programme was postponed till after the war. Cf. Governo Generale AOI to Ministero dell'Africa Italiana, 9 November 1940, ACS, MAI, b. 104.

24 PODESTÂ, Gian Luca, I luoghi della cultura nell'Impero fascista, in SCARPA, Domenico (a cura di), Atlante della letteratura italiana, vol. 3, Dal Romanticismo ad oggi, Torino, Einaudi, 2012, pp. 655-670. 
restaurants and clubs, , patronized by military personnel, workers and by the Italian nouveaux riches who, as Indro Montanelli denounced in his book XX Battaglione Eritrea (20 ${ }^{\text {th }}$ Eritrean Battalion) lived a upper-class lifestyle, which went against the Fascist imperial ethos, thus betraying the ideal purpose of the African wars.

The PNF was a crucial instrument in molding colonial society in a fascist sense and also in the involvement and training of those Africans destined to fill some inferior role in the civil administration or in the army, through school education and the Gioventù Indigena del Littorio (GIL - the fascist indigenous youth organization). Italian colonists' degree of adhesion to the fascist party was massive, well above the percentage of party members back in Italy, especially among women: at the end of 1939 the PNF had 51.146 members in the colonies, whilst pending applications for membership amounted to 24.397 and those transferred from Italy were 9.950. There were 3.308 women enrolled in the fascist organizations (12.8\% of the female population) ${ }^{25}$. There also were 237 fascist working men's clubs with 38.235 members and 106 sports societies with 19.822 members.

A remarkable effort was made to establish a school system in AOI, both for Italians and for Africans ${ }^{26}$. Schools for Italian students were built in thirty locations. Some secondary schools of all kinds were also created in the main towns. In Eritrea, where the number of Italian families was higher than in the rest of AOI, the educational system was structured in the same way as in Italy: in 1938/1939 primary schools for Italians counted 107 classes in total, attended by 2.554 pupils, of whom 1,793 in the capital alone. In Asmara the lyceum (grammar school) had 470 registered students, while the technical college had 341 pupils. Between 1937 and 1938, in the whole of AOI, teachers had increased from 209 to 380 . On the eve of the war some teacher training schools were also due to be opened.

Colonisation represented a major turning point in the life of thousands of settlers. The regime conceived a new social plan for the empire, consisting of a society made up by brave and hard-working farmers, virtuous and frugal, «all equal and all poor enough ${ }^{27}$, as Mussolini loved to say, emphasizing the ethics of sobriety that he wished to inoculate Italians with, as a remedy for the evils of bourgeois hedonism. The situation was slightly different in Eritrea. Asmara's development had been chaotic.

25 Popolazione nazionale femminile residente in AOI e iscritte ai fasci femminili al 31 dicembre 1939, ACS, MAI, b. 2123.

26 «La scuola e le istituzioni educative», in Gli Annali dell'Africa Italiana, 3/1940, p. 670; Funzionamento scuole AOI, ACS, MAI, b. 161.

${ }_{27}$ CIANO, Galeazzo, Diario 1937-1943, Milano, Rizzoli, 1990, p. 261. 
Each firm (especially transport and building companies) had built their own factories and storehouses in the suburbs, also providing them with accommodation for their employees. Of course dozens of unauthorised edifices had sprung up. To remedy this situation at least in part, the local government granted some lots of land free of charge to war veterans authorised to remain in East Africa, who managed to build their own homes with government help and the workers' club's contribution. Besides public initiative however, some large private companies in Asmara were allowed to build new residential areas for Italians and Eritreans. These new homes somewhat helped to keep rent prices under control, though they were still very high practically everywhere. In all cities, but especially in Addis Ababa, Asmara and Massawa, a thriving black market of rented houses and rooms developed at the hands of both Italians and Africans. In Eritrea, near the strategic hubs where companies had dislocated their logistic quarters during military operations, there materialised almost out of nothing some new urban agglomerates, such as Dek'emhare and Nefasit. The most fascinating case was that of Mai Edaga, also called Capronia because it had developed around the Caproni factory in the Gura plains. Not only had the industrial buildings been added to the few preexisting tukuls, but also houses and villas for the Italian employees, technicians and workers, as well as new huts for the indigenous workforce, a school, a nursery, a post office, the workers' club, a church, some shops and great water storage tanks: Capronia had become a small town in its own right, built along the most modern criteria according to a rational town planning scheme, and capable of a truly autonomous life.

It is difficult to formulate any judgement on Italian East Africa's economic system. Certainly the empire had helped Italy to come out of the Depression; it is also just as evident, however, that the colonial economy, because of the way it was structured, could have survived only if supported by a high level of public expenditure. Its long term prospects, on the contrary, would have been problematic. But as I have said, Mussolini's objectives were mainly of a political and ideological-spiritual nature. However, if as a "myth" for mobilising the nation the empire had succeeded, it is also true that the ambitious project of social engineering dreamt by Il Duce (of which the imperial towns were an important element) was not proceeding according to his wishes. As we have noted as regards racial policy, it was as if there were two models existing in parallel in the creation of imperial society: on one hand Mussolini and his totalitarian directives irradiating from Rome, on the other the élite of colonial civil servants who held more traditional views along classic colonialist lines. It is instead interesting to note that, given the importance attributed to symbolic factors by the fascist regime, the innovating and revolutionary spirit of modern architects - real 
technocrats devoted to regenerating traditional society - coincided to a greater extent with the totalitarian utopia. But the settlers coming to East Africa did not seem to resemble the myth of the "new Italian" either: not only did they break the taboo of inter-racial sexual relationships, but also, influenced by the climate of mobilisation in the empire, which favoured the creation of wealth and social climbing, they let themselves be seduced by the virtues of individualism and capitalism, turning, in their new country, into entrepreneurs and bourgeois, almost unconsciously breaking loose from fascism in their social and consumer behaviours; ideally, however, the Duce myth would fascinate them till the end of their lives. As the OVRA (the secret police) reported to Mussolini, «the environment of the colony was among the worst as regards bourgeois spirit» 28 .

\section{Conclusions}

The Italian colonial towns were important tools for spreading Western lifestyles. In the colonies even lower-class Italians (often farmers) acquired typically bourgeois habits and practiced sports (like tennis) which in the mother country were reserved to the higher classes. In Eritrea Italians and Africans even shared in the foundation and growth of cities (built after 1900). Western lifestyles and sports activities also influenced the indigenous elite, as well as those Africans working for the Italian administration (soldiers, drivers, interpreters, factory workers). Tourism also played an important role. Moreover, the fascist regime attributed a crucial importance to school education in the task of forming its colonial subjects. A similarly relevant function was carried out by the Fascist National Party and its collateral organizations. Cinemas, theatres, the press and above all the radio were considered the most important instruments for the persuasion and involvement of both settlers and indigenous people in the regime's policies.

${ }^{28}$ From a secret police report (Informativa dell'OVRA) enclosed in: Meregazzi to Teruzzi, 5 January 1939, ASDMAE, ASMAI, ASG, b. 265. 


\section{* The author}

Gian Luca Podestà is full Professor of Economic History at the University of Parma and Contract Professor of Economic History at Bocconi University. His Research Areas are Public Finance in the Modern Era; Economics, Employment, politics and Society in the Italian Colonies in the XIX and XX Centuries; the Italian Public Industry during the Second world War; the Italian Iron and Steel Industry after the War of Ethiopia.

URL: < http://www.studistorici.com/progett/autori/\# Podestà >

\section{Per citare questo articolo:}

PODESTÀ, Gian Luca, «The Eighth Vibration. Asmara and Dek'emhare, Cities of Work, Cities of Leisure», Diacronie. Studi di Storia Contemporanea : Le città di Babele, 29/3/2015,

URL:< http://www.studistorici.com/2015/03/29/podesta_numero_21/>

Diacronie Studi di Storia Contemporanea $\mathcal{\beta}$ www.diacronie.it

Risorsa digitale indipendente a carattere storiografico. Uscita trimestrale. redazione.diacronie@hotmail.it

Comitato di redazione: Jacopo Bassi - Luca Bufarale - Elisa Grandi - Deborah Paci - Fausto Pietrancosta - Matteo Tomasoni - Luca Zuccolo

Diritti: gli articoli di Diacronie. Studi di Storia Contemporanea sono pubblicati sotto licenza Creative Commons 2.5. Possono essere riprodotti a patto di non modificarne i contenuti e di non usarli per fini commerciali. La citazione di estratti è comunque sempre autorizzata, nei limiti previsti dalla legge. 